\title{
Post-monumentalne miejsca pamięci jako aktywne narzędzia doświadczenia (post)holocaustowego i (post)pamięci
}

\author{
Post-Monumental Places of Memory \\ as Active Tools in (Post-)Holocaust and (Post-)Memory Experiences
}

\begin{abstract}
The aim of the article is to answer to the question of how best to commemorate the Holocaust in the post-memory era. One possible answer is to create temporary post-monuments which require engagement only from viewers who want and need it. The post-monument relates to cultural, social, and also individual memory. It commemorates forgotten places and individual experiences, encouraging dialogue among viewers. Engaging viewers and inviting them to reconstruct history is one way that the trauma of past generations can be commemorated by contemporary generations. In order for history to remain vibrant, and its message to have a performative function, its memory must live on through successive generations. The temporary nature of the post-monument allows it not only to commemorate, but also to thematize the process of memory erasure over time. In the article, the above observations are presented in reference to the theory of memory, the philosophy of postmodernism, the idea of homo holocaustus, in order to compare the post-monument to more traditional forms of commemoration alongside selected examples of post-monuments.
\end{abstract}

Key words: post-monument, postmodernism, memory, post-memory, postHolocaust

Streszczenie: Artykuł jest próbą znalezienia odpowiedzi na pytanie, w jaki sposób upamiętnić Holokaust w erze postpamięci. Jedną z możliwych odpowiedzi jest tworzenie tymczasowych, wymagających zaangażowania od chcących i potrzebujących tego odbiorców post-pomników. Post-pomnik odwołuje się do 
kulturowej i społecznej, ale również indywidualnej pamięci. Upamiętnia miejsca zapomniane, doświadczenia jednostkowe, zaprasza odbiorców do dialogu. Uaktywnienie oglądających, zaproszenie ich do wspólnego odtwarzania historii pokazuje, w jaki sposób traumę minionych pokoleń mogą przepracowywać i upamiętniać współczesne pokolenia. Aby historia była wciąż żywa, aby jej przesłanie posiadało funkcję performatywną, musi być podtrzymywana przez współczesne pokolenia. Tymczasowość post-pomnika zaś powoduje, że nie tylko upamiętnia, ale i tematyzuje proces umykania pamięci wraz z czasem jej zacierania. W artykule powyższe spostrzeżenia są przedstawiane w kontekście teorii pamięci, filozofii postmodernizmu, idei homo holocaustusa, w porównaniu post-pomnika do pomnika oraz na wybranych przykładach post-pomników.

Słowa kluczowe: post-pomnik, postmodernizm, pamięć, post-pamięć, post-Holokaust

Pomnik jest także dziełem sztuki, zapewnia się mu zatem taki szeroki zakres autoprezentacji, jakim obdarzamy dzieło sztuki. Pomnik więc z jednej strony może być po prostu czymkolwiek między dziełem sztuki, które całkowicie pochłania naszą uwagę, kosztem tego, co przedstawia, a z drugiej strony przeciw-pomnikiem, który właśnie przed chwilą się unicestwił, nie chcąc być niczym innym, jak tylko zwykłym wskaźnikiem lub drogowskazem.

F. Ankersmit: Pamiętając Holocaust

Postmodernizm w zupełnie nowym świetle stawia sposób opowiadania o przeszłości. Jak zauważa Susannah Radstone, dekonstruuje on myślenie o historii, jej reprezentacji i pamięci. Przenosi punkt ciężkości ze społecznego i publicznego doświadczenia na podejście indywidualne i prywatne, a czasami nawet intymne ${ }^{1}$. Odchodzi od wielkich, społecznych narracji, idei pamięci zbiorowej, akcentuje regionalny, lokalny czy wręcz jednostkowy punkt widzenia ${ }^{2}$, tworzy lokalną/prywatną sferę publiczną (local public spheres). Przywołując rozważania Hannah Arendt ${ }^{3}$, można stwierdzić, że w myśli postmodernistycznej sfera publiczna jawi się jako wielopoziomowa konstrukcja, złożona z oddzielnych, fragmentarycznych obszarów pub-

${ }^{1}$ S. Radstone: Reconceiving Binaries: The Limits of Memory. „History Workshop Journal" 2005, no 59, s. 140.

2 EAdem: Screening Trauma: Forrest Gump, Film and Memory. In: Memory and Methodology. Ed. S. Radstone. Oxford-New York 2000, s. 84.

${ }^{3}$ H. Arendt: The Human Condition. Chicago 1998; Eadem: Kondycja ludzka. Przeł. A. Łagodzka. Warszawa 2000. 
licznych pojedynczych obywateli. Każdy z nich może bezpośrednio wyrazić swój punkt widzenia i przedyskutować go z innymi.

Refleksja postmodernistyczna w ten sposób potęguje siłę subiektywizmu, indywidualnego oglądu świata, pluralistycznej interpretacji, wzmacnia dialogiczność i możliwości negocjacyjne. Jest zatem myślą, która próbuje nadążyć za zmieniającym się światem, ale zawsze w odniesieniu do tego, co było. Dowodzi zmienności i ewolucji. To, co nowoczesne, opisuje jako postnowoczesne czy ponowoczesne, a to, co aktualne, jako postmodernistyczne. Postmodernizm jawi się, jak podkreśla Andrzej Szahaj ${ }^{4}$, jako teoria wskazująca na będące wynikiem konstrukcji kulturowych istotne procesy przemian, które należy bacznie śledzić i opisywać. Podlega przy tym współczesnym wartościom, prezentuje i definiuje kulturę w procesie transformacji, a więc - uzależnioną od mocy przekonań, które warunkują myślenie, postrzeganie, zachowanie, procesy tożsamościowotwórcze, zdolności partycypacji w rozmaitych wspólnotach oraz interpretacje poznawcze ${ }^{5}$.

Tak postrzegany postmodernizm nie tyle przedstawia kres historii, jak twierdzi Gianni Vattimo, ile pozwala na wypowiedzenie wielu historii, „podlega różnym "nachyleniom interpretacyjnym «" zuje nowe doświadczanie i historii, i czasowości. A co za tym idzie, zmusza do przedefiniowania kategorii pamięci, która staje się pewną wersją historii. Jak zaznacza Marita Sturken ${ }^{7}$, pamięć jest w istocie postmodernistyczna. Tematyzuje „symboliczne wykluczenie”, może pełnić funkcję uzdrowienia, służy transcendencji. Stanowi narracyjny proces podejmowania wątków traumy, katharsis i odkupienia. Jest opowiadaniem o przeszłości, potrzebą szukania informacji o niej, formą interpretowania. Co ważne, proces pamiętania, przypominania czy zapominania ma charakter indywidualny, podlega prawom wewnętrznego świata, emocji, analiz hermeneutycznych. Postmodernizm zatem prywatyzuje historię. Walter Benjamin ${ }^{8}$ podkreśla, że konstruowanie spójnej, jednolitej narracji przeszłości

${ }^{4}$ A. Szahaj: Zniewalajaca moc kultury. Artykuty i szkice z filozofii kultury, poznania i polityki. Toruń 2004.

${ }^{5}$ Ibidem, s. 9.

${ }^{6}$ G. Vattimo: Postnowoczesność i kres historii. Przeł. B. Stelmaszczyк. W: Postmodernizm. Antologia przekładów. Wybrał, oprac. i przedmową opatrzył R. Nycz. Kraków 1998, s. 128.

7 M. Sturken: Tangled Memories: The Vietnam War, the AIDS Epidemic, and the Politics of Remembering. Berkley 1997.

${ }^{8}$ W. Benjamin: On the Concept of History. https://www.marxists.org/reference/ archive/benjamin/1940/ history.htm [dostęp: 7.06.2019]. 
staje się niemożliwe. Zastępuje ją strategia mikronarracji, nazywana również mikrologią (micrology), będąca zbiorem subiektywnych, jednostkowych, retrospektywnych przebłysków pamięci. Coraz częściej jest ona niepodporządkowana społecznej polityce pamięci, odległa od kontekstu historycznego oraz specyfiki historycznej. ${ }^{9}$. To pamięć lokalna/prywatna, pamięć konkretnego miejsca. Oczywiście, nie pozostaje ona w oderwaniu od pamięci zbiorowej, państwowej, europejskiej. Lokalna pamięć czy nawet pamięć indywidualna staje się elementem większej układanki. Zmienia się jedynie sposób jej powstawania. Układanie współczesnych puzzli pamięci nie zaczyna się od wiedzy, jak ma wyglądać gotowy obraz, i zbudowania ramy, ale od znalezienia dowolnego elementu układanki, do którego dokłada się kolejne. To nie budowa od ogółu do szczegółu, ale odwrotnie - od szczegółu do ogółu. Takie przeniesienie punktów ciężkości powoduje, że sztuka pamięci staje się autentyczna, a, jak podkreślał już w latach 30. poprzedniego wieku Walter Benjamin ${ }^{10}$, sztukę determinuje jej autentyczność, jej Jetztzeit. To współczesność decyduje o tym, w jaki sposób będzie odbierana przeszłość. W centrum historii znajduje się relacja indywidualna świadka, indywidualna pamięć lub interpretacja, a z wielu takich wersji powstaje multiwersalistyczna opowieść. Nie ma zatem jednej kanonicznej interpretacji, ale ciąg przedstawień, które budują ży wą historię.

W postnowoczesnym mówieniu o tożsamości, pamięci, historii i upamiętnianiu to właśnie interpretacja wydaje się słowem kluczem. Wojciech Kalaga traktuje ją jako sposób egzystencji. Powołując się na teorie Charlesa Taylora, Martina Heideggera, Hansa-Georga Gadamera, Paula Ricœura, Charlesa Peirce'a, nazywa ludzi dyskursywnymi konstruktami, tworzącymi system kulturowej interpretacji, roli i znaczenia. $Z$ interpretacji wyłania się ludzka tożsamość, a ta z kolei łączy się z pamięcią. Kalaga pisze: „co powiedzieliśmy o interpretacji, dotyczy naszej egzystencji - i to samo może być powiedziane o pamięci"111. Podkreśla również, że każdy element

9 Zob. K.L. KLeIN: On the Emergence of Memory in Historical Discourse. „Representations" 2000, no 69, s. 127-150. http://marcuse.faculty.history.ucsb.edu/classes/201/articles/00KleinMemoryHistDiscourseRep.pdf [dostęp: 29.04.2019]; IDEM: O pojawieniu się pamięci w dyskursie historycznym. Przeł. M. ВаŃкоwsкI, „Konteksty" 2003, nr 3/4.

${ }^{10}$ W. Benjamin: The Work of Art in the Age of Its Technological Reproducibility. In: Walter Benjamin: Selected Writings. Vol. 3: 1935-1938. Eds. H. EILAnd, M.W. Jennings. Cambridge-London 2002, s. 22.

${ }^{11}$ W. Kalaga: Memory, Interpretation, Identity. Przeł. J. Pytalski. „Teksty Drugie" 2016, nr 1, s. 23. 
tożsamości zakorzeniony jest $\mathrm{w}$ materii pamięci, a jej utrata lub brak oznacza w rzeczywistości utratę tożsamości. I tak jak jej budulec stanowi interpretacja, tak pamięć dostarcza interpretacji materiału.

Z koncepcją Kalagi koresponduje bardzo wyraźnie idea post-pomnika ${ }^{12}$. Ta forma upamiętnienia wymaga bowiem intensywnej analizy, kreatywności oraz interpretacji, ściśle połączonej z pamięcią. Post-pomnik jest formą komunikacji, która wymaga współuczestnictwa, w procesach aktywnej interpretacji, łączenia faktów oraz spotkania przeszłości z teraźniejszością konstytuującą społeczną tożsamość. Odwołuje się on nie tylko do kulturowej i społecznej pamięci, do jej kulturowej i lokalnej interpretacji, ale również sięga do pamięci indywidualnej, doświadczenia jednostki intepretującej i jej historii. Pamięć głoszona przez post-pomnik to kolekcja wielu pamięci. Kalaga za Bergsonem porównuje pamięć do kuli śniegowej. Tę analogię można zastosować do omówienia post-pomnika budowanego z wielu jednostkowych interpretacji i pamięci, opartej na zasadzie dialogu i negocjacji. Na jedną interpretację nakładane są kolejne przez uczestników procesu analizy, przez późniejsze pokolenia, dopisywane wciąż i wciąż na nowo.

Taka relacja tworzy post-historię, która staje się wielogłosem małych narracji i rozmaitych emocji. Opowieść wielu buduje historię wielu, scala ich relacje, tworząc pewną glokalną wizję. Stanowi przeciwwagę dla kanonicznej wersji przeszłości, zanurza ją nie tylko lokalnie, ale i globalnie, podkreślając jej wyjątkowość, niezwykłość na szerszej arenie, niepozostającej $\mathrm{w}$ izolacji, chcącej partycypować $\mathrm{w}$ debacie na forum. Glokalność pamięci odwołuje się do post-

${ }^{12}$ Zdecydowałam się na stosowanie terminu "post-pomnik”. Wydaje się, że termin ten $\mathrm{w}$ pełni oddaje to, czym jest współczesna forma upamiętniania traumy Holokaustu. Określenia najczęściej stosowane do opisu post-pomnika, czyli przeciw-, anty-, nie- lub kontr-pomnik (any-, non-, co-, unter-), pomnik rekonstrukcyjny, nietradycyjny czy kontr-hegemoniczny (deconstructive, non-traditional, counter-hegemonic monument) lub negatywna forma (negative-form) kładą akcent na zaprzeczenie idei monumentu, negację poprzedniej wizji pomnikowości. Tymczasem post-pomnik nie odrzuca tego, co było, ale czerpiąc z poprzednich doświadczeń, form, definicji i celów, dostosowuje je czy przekształca. Termin „post-pomnik” wydaje się również odpowiedniejszy niż kombipomnik. Idea post-pomnika zatem, podobnie jak post-modernizm, pokazuje pewną ciągłość, wskazuje na transformację, a nie zaprzeczenie czy odrzucenie. Ponadto termin post-pomnik pozwala włączyć do kategorii pomników również działania spontaniczne i nieformalne, takie jak instalacje, murale i inne miejskie formy upamiętniania, rozszerzając pojęcia anty-pomnika i włączając do mówienia o pomnikach również pomnik dekonstrukcyjny, oznakowania nie-miejsc pamięci, nie-tradycyjne pomniki etc. 
modernistycznej świadomości różnorodnych czasów, pokoleń, analiz przeszłości czy dziedzictwa. Za jej pośrednictwem można dostrzec polifoniczność i różnorodność rzeczywistości, skupić się na wielości doświadczeń. Post-historia to glokalna opowieść o świecie, który się zmienia, o jego różnym postrzeganiu; opowieść niekompletna, rozwijająca się wraz z czasem i kulturą. To także historia $\mathrm{z}$ otwartym zakończeniem, które będzie się zmieniało, tworzona dla wielu i przez wielu. Ta polifoniczność nie pozwala na zakorzenienie się w jednej perspektywie, nie osądza, nie jest skierowana tylko do danej grupy, nie zakłada określonych wniosków. Pamięć postrzegana w takim ujęciu jest szczególnie istotna $\mathrm{w}$ dobie postpamięci.

\section{Postpamięć post-Holokaust}

Marianne Hirsch ${ }^{13}$ zaznacza, że postpamięć ${ }^{14}$ to pamięć drugiego pokolenia, oddalonych czasowo i przestrzennie potomków generacji, która doznała ciężkich przeżyć. Stanowi ona ponadpokoleniową przestrzeń pamięci zapośredniczonej, a czasem i fantazmatycznej, rodzaj utożsamienia się z ofiarą lub świadkiem traumatycznych wydarzeń ${ }^{15}$. Jest aktywną formą pamiętania, której związek z przeszłością jest zapośredniczony nie przez przypomnienie, a przez wkład wyobraźni i interpretacji. To pamięć kreacyjna oraz projekcyjna ${ }^{16}$, gdyż jest dopowiadana, fabularyzowana, odrzucająca dokumentarność, a także performatywna - nieustannie powtarzana. Jak pisze Patrick H. Hutton ${ }^{17}$, pamięć ta składa się z dwóch momentów: powtarzania i wspominania. $\mathrm{W}$ obu przypadkach chodzi o ponowne przywoływanie przeszłości w teraźniejszości, cykliczny mechanizm powracania do kluczowych zagadnień: winy, agresji, tragedii, emocji, traumy. To pamięć przyswajalna, dostępna, zobowiązująca i determinująca do nieustannego powielania ${ }^{18}$. I właśnie fakt repetycji

${ }^{13}$ M. Hirsch: Family Pictures: Maus, Mourning and Post-Memory. „Discourse”, Winter 1992/1993.

${ }^{14}$ EAdem: Family Frames: Photography, Narrative, and Postmemory. CambridgeMassachusetts-London 1997.

15 EAdem: Surviving Images: Holocaust Photographs and the Work of Postmemory. „The Yale Journal of Criticism" 2001, vol. 14, no 1, s. 11.

${ }^{16}$ EAdem: The Generation of Postmemory: Writing and Visual Culture After the Holocaust. New York 2012.

17 P.H. Hutton: History as an Art of Memory. Hanover-London 1993.

${ }^{18}$ Za: E. Hoffman: After Such Knowledge. A Meditation on the Aftermath of the Holocaust. London 2005. 
doświadczeń oraz przeżyć jest tak istotny w pamiętaniu trzeciego pokolenia. Generacja ta zdana jest tylko i wyłącznie na powtarzanie tego, co było. I choć dorastała w cieniu opowieści o przeszłej traumie, nie potrafi jej ani zrozumieć, ani w pełni zrekonstruować.

Postmemorialna sytuacja podmiotu, pozbawienie go dostępu do doświadczenia rzeczywistego, zapośredniczenie jego pamięci w opowieści innych czy archiwaliach, pociąga za sobą, jak podkreśla Bartosz Dąbrowski, „znaczące [...] zaangażowanie, zakłada bowiem projekcyjne wytworzenie brakującej historii w oparciu o zastane znaki, fragmentaryczne opowieści i zachowane materialne relikty. $\mathrm{Z}$ tego powodu doświadczenie $\mathrm{w}$ wymiarze postpamięci przyjmuje wyjątkową modalność oddziaływania, zbliżoną do opóźnionego i odtworzonego działania traumatyzującego wydarzenia"19.

To pamięć obciążona obowiązkiem podtrzymywania traumy niejako „W zastępstwie podmiotów faktycznie skrzywdzonych" ${ }^{\prime 20}$ potrzebą eksplorowania cierpienia pokoleń lub zrozumienia cierpienia cudzego. Zygmunt Bauman ${ }^{21}$, zważywszy na to obciążenie, wspomina o syndromie przeżytnika, czyli o dziedzictwie cierpiętnictwa.

Mówi się o pokoleniu dziedziców traumy, osób urodzonych po II wojnie światowej, ale naznaczonych jej historią, przejmujących wojenne traumy. Można nawet stwierdzić, że nie istnieje współczesna pamięć, która nie otarłaby się o II wojnę światową. To pamięć odziedziczona, w pewnym sensie performatywna, taka, którą jednostka została dotknięta i którą w swoim rozumieniu powinna kultywować i przekazywać. Pamięć ta budowana jest z dystansu, na podstawie relacji i doświadczeń przeżyć innych. Postpamięć jednak jest na tyle silnie obecna we współczesności, że staje się pamięcią własną pokolenia dystansu, ale tylko tego, które miało szansę wysłuchać relacji świadków. Pamięć o traumie przodków, cytując Michaela Schudsona ${ }^{22}$, charakteryzuje grupę pokoleniową, czyniąc ją dłużnikiem pamięci i odpowiedzialną za moralny/etyczny obowiązek jej kontynuowania. Anna Neumannn ${ }^{23}$, rozważając zagad-

19 B. DĄвrowsкi: Postpamięć, zależność, trauma. W: Kultura po przejściach, osoby z przeszłości. Polski dyskurs postzależnościowy - konteksty i perspektywy badawcze. Red. R. Nycz. Kraków 2011, s. 258.

${ }^{20}$ A. Мach: Polska kondycja posttraumatyczna. W: Kultura po przejściach..., s. 223.

${ }^{21}$ Z. Bauman: Świat nawiedzony. W: Zagłada. Wspótczesne problemy. Red. P. CzAPLIŃSKI, E. DomańsKa. Poznań 2009.

${ }^{22}$ M. Schudson: Watergate in American Memory: How We Remember, Forget, and Reoconstruct the Past. New York 1992.

${ }^{23}$ Zob. A. Neumann: On Experience, Memory, and Knowing: A Post-Holocaust (Auto)Biography. „Curriculum Inquiry” 1998, no 28(4), s. 425-442. 
nienie ery post-Holokaustu, podkreśla, że istotna jest ścisła relacja między historią a biografią (również w kontekście pokoleniowym). Biografie nie mogą istnieć bez kontekstu historycznego, nie są już tylko indywidualne, ale wspólne, rozumiane przez odwołanie do tego, co minione.

Przeszłość w przypadku drugiego pokolenia determinuje i organizuje teraźniejszość, obecną biografię, a pamięć innych jest odczuwana jak własna. Z czasem i wraz z pojawianiem się kolejnych generacji jej siła jednak zanika. Te chociaż dorastają wśród narracji o II wojnie światowej i Holokauście, wydarzenia te traktują jako coraz bardziej odległe i niezrozumiałe.

Jak zatem skutecznie przekazać im doświadczenie przeszłości, aby stała się ona ich pamięcią? Dystans ten mają zmniejszyć lub znieść post-pomniki, których twórcy odpowiadają na współczesną potrzebę praktyki pamięciowej. Autorzy post-pomników nie tylko afirmują przeszłość, ale też zawłaszczają minione doświadczenie, próbują je powtórzyć, odtworzyć lub chociażby znaleźć jego konkretną reprezentację. Hołdują idei Dominicka LaCapry ${ }^{24}$, który zaznacza, że przeszłość żyje w doświadczeniu, rozszerza to, co minione, na teraźniejszość i przyszłość. Przeszłość czyni się elementem teraźniejszości, albowiem tylko to, co dzisiaj odczuwane, miarodajne, doznane bywa zachowywane $\mathrm{w}$ pamięci. Zmniejszenie dystansu służy jeszcze jednemu celowi, o którym wspomina niemiecki artysta konceptualny Jochen Gerz. Pisze on bowiem, że „im większy dystans czasowy, tym bardziej realna staje się możliwość, że Holokaust będzie zapomniany, relatywizowany albo się powtórzy"25. Stąd potrzeba przełamania dystansu i uczynienie pamięci o przeszłości częścią współczesnego doświadczenia. Jak zauważa Kirk Savage ${ }^{26}$, post-pomniki przede wszystkim upamiętniają mroczne wydarzenia, takie jak Holokaust, ludobójstwo czy wojna i odwołują się najczęściej do pamięci problematycznej, niepokojącej. To zatem działania, które upamiętniają raczej słabości, a nie siłę, odwołują się do antywzorów, służą pamięci ku przestrodze.

${ }^{24}$ D. LaCAPra: Writing History, Writing Trauma. Baltimore 2001.

${ }^{25}$ J. Gerz: [Eesej bez tytułu]. W: Wielogłos o Zagładzie. Red. M.A. Ротоска. Kraków 2018, s. 66.

${ }^{26}$ K. Savage: Monument Wars: Washington, D.C. the National Mall, and the Transformation of the Memorial Landscape. London 2011, s. 236-244. 


\section{Post-pomnik}

Monumentalne pomniki, jak twierdzi Robert Musili27, są niewidoczne. „Na tym świecie nie ma nic bardziej niewidzialnego niż pomniki. Bez wątpienia są wznoszone, aby je zobaczyć - w rzeczywistości, aby przyciągnąć uwagę. Ale jednocześnie są impregnowane czymś, co odpycha uwagę. Jak kropla wody na skórze olejnej, uwaga spływa po nich bez zatrzymywania się na chwilę"28. Werner Fenz, komentator refleksji Musila, pisze: „pomniki tamtych czasów, bez względu na to, czy nadal istnieją czy są rekonstruowane, z pewnością są niewidzialne szczególnie dlatego, że nasza historyczna świadomość nie pozwala już na spokojne rozpamiętywanie tamtych czasów" ${ }^{\prime 29}$. Również Andreas Huyssen ${ }^{30}$ zaznacza, że w Niemczech obsesja wystawiania pomnikowych miejsc pamięci w latach 80. prowadziła de facto do uczynienia przeszłości niewidoczną. Nagromadzenie, nadmierna kumulacja powoduje, że stają się niezauważalne i (o)mijane bezmyślnie. Monument bowiem, jak podkreśla James E. Young, poniekąd zwalnia z obowiązku pamiętania: „Przejmując na siebie rolę kultywowania pamięci, pomniki zdają się uwalniać widzów od jej brzemienia" ${ }^{31}$. Dzieje się tak być może dlatego, że pomnik buduje pamięć zbiorowa, narzuca kanoniczną interpretację uznaną przez instytucje czy sprawujących władzę, która uzgadnia jego kształt i wymowę. Pomnik opowiada monumentalną wersję historii, która niekoniecznie musi być odzwierciedleniem prawdy, ma jedynie ujednolicać pewne opowieści tak, by były akceptowalne w danej zbiorowości lub tę zbiorowość budowały. Jak zauważa dalej

27 R. Musil: Die Denkmale. In: Idem: Nachlass zu Lebzeiten. Hamburg 1980; angielska wersja w: R. MusiL: Posthumous Papers of a Living Author. Transl. P. Wortsman. Colorado 1987, s. 61.

${ }^{28}$ IDEM: Posthumous..., s. 61.

${ }^{29}$ W. FEnz: The Monument Is Invisible, the Sign Visible. "October" 1989, vol. 48 , s. 78.

30 A. Huyssen: Monumental Seduction. In: Acts of Memory. Cultural Recall in the Present. Eds. M. BAL, J. Crewe, L. Spitzer. Dartmouth 1999, s. 191-207; A. HuysSEN: Monumental Seduction. „New German Critique” 1996, no 69, s. 181-200. http:/4.s32.scripts.mit.edu/fall2014/wp-content/uploads/2014/10/Monumental-Se duction.pdf [dostęp: 29.04.2019].

${ }^{31}$ J.E. Young: Pamięć i kontr-pamięć. W poszukiwaniu społecznej estetyki pomników Holokaustu. Tłum. G. DĄBrowski. „Literatura na Świecie” 2004, nr 1-2, s. 245-266. Zob. też: J.E. Young: Pamięć i kontrpamięć. W poszukiwaniu społecznej estetyki pomników Holokaustu. Tłum. G. DąBrowski. W: Reprezentacje Holokaustu. Red. W. Jarkiewicz, M. SzuSter. Kraków-Warszawa 2014. 
Musil: pomniki są magnesami uwagi zamiast jej deflektorami. Nie zmieniają sposobu myślenia, nie zachęcają do samodzielnej analizy. Rosalind E. Krauss ${ }^{32}$ w swoich rozważaniach idzie o krok dalej i zaznacza, że tradycyjne pomniki często nie upamiętniają wydarzeń, którym są poświęcone, ale zakopują je pod grubą warstwą mitu narodowego. Zwraca uwagę, że są one waloryzowane negatywnie, jako nie-krajobraz, nie-architektura.

Można przyjąć, że pomniki w pewnym sensie zwiastują epokę postmonumentalna, w której uwaga odbiorcy zostanie przekierowana na samodzielny proces myślowy. Bez wątpienia bowiem tradycyjne monumenty tracą na znaczeniu, są już tylko elementem wielkiej narracji aktualizowanej podczas obchodów państwowych lub medialnego dyskursu, gdy społeczeństwo wchodzi w dialog na temat pomnika lub go dewastuje.

To koniec monopolu na historię tworzoną na podstawie kilku wybranych źródeł. W jego miejsce pojawia się koncepcja czy też wizja post-monumentalna oraz potrzeba konstrukcji post-monumentalnego obrazu. Wydaje się zatem, że post-pomniki realizują zadania, które Peter Steinbach przypisał pomnikom - przerzucają mosty między generacjami, budują więzi, stają się upomnieniem, pobudzają do refleksji i kontrowersji, skłaniają do zadawania pytań i pomagają w uzyskaniu odpowiedzi ${ }^{33}$.

Połączenie treści oraz kontekstu przestaje być efektem inicjatywy czy autorytetu instytucjonalnego i coraz częściej wynika z inicjatywy oddolnej lub twórczego apelu artystów. Post-monumentalne może stać się odwołanie do kategorii pustki czy braku - nie-miejsca pamięci, ale także anty-monumentalności. Toteż post-pomniki unikają symbolizacji, patosu, majestatyczności i sięgają po ikonografię nicości ${ }^{34}$. Istotne okazuje się działanie przypadku i chwili, a także współdziałanie przestrzeni medialnych, przykładowo wówczas, gdy same obiekty pozostają niewidoczne do momentu zwrócenia na nie uwagi, uruchomienia ich bytności za pomocą choćby informacji internetowych.

Post-pomnik tematyzujący Zagładę to element sztuki pamięcisi, która odwołuje się nie tylko do przypominania, ale również wy-

32 R.E. Krauss: Oryginalność awangardy $i$ inne mity modernistyczne. Tłum. M. Szuba. Gdańsk 2011.

33 P. Steinbach: Opór - sprzeciw - rezystencja. Postawy społeczności niemieckiej w Trzeciej Rzeszy a pamięć zbiorowa. Tłum. I. Ewertowska-Klaja. Poznań 2001, s. 258.

34 E. Jedlińska: Sztuka po Holokauście. Łódź 2001, s. 108.

35 Za: F. Yates: The Art of Memory. London 1966. 
obraźni czy reprezentacji i wykorzystuje w tym celu konkretne miejsce. Unika on ideologiczno-kulturowych wpływów, sięgając po doświadczenie jednostkowe. To, na ile dana przestrzeń pełni funkcję lieux de memoire, zależy nie tyle od kontekstu kulturowego, ile od indywidualnej interpretacji i pamięci, zgodnie z zasadą Amosa Funkensteina ${ }^{36}$, który twierdzi, że tylko jednostki są w stanie pamiętać i zarażać tym działaniem innych, budując $\mathrm{w}$ ten sposób pamięć kolektywną i czyniąc pamiętanie wyjątkowym. Post-pomnik - depozyt jednostkowej pamięci - służy zatem jako propozycja wzorca pamiętania oraz upowszechniania wiedzy o przeszłości poprzez nakłanianie odbiorcy do szukania informacji o konkretnym miejscu, do emocjonalnego przeżycia i utożsamiania się z pamięcią jednostki. Szczególnie istotne okazuje się tu międzypokoleniowe doświadczenie, które podlega wizualizacji, a nierzadko również teatralizacji.

Post-pomnik, zaznaczając na mapie pamięci nie-miejsce pamięci, miejsce zapomniane, pominięte, na powrót czyni je znaczącym. Idea pustki, zapomnienia czy braku pamięci jest bardzo ważna $\mathrm{w}$ kontekście mówienia o postpamięci w okresie post-Holokaustu - i to z dwóch przyczyn. Po pierwsze, współczesność naznaczona jest początkiem amnezji o II wojnie światowej i Holokauście. Coraz częściej można przeczytać raporty o braku wiedzy o Holokauście i II wojnie światowej wśród młodszych europejskich i amerykańskich pokoleń. Jelena Subotic ${ }^{37}$ pisze przykładowo o tym, w jaki sposób wojny jugosłowiańskie przesłoniły pamięć o Holokauście, która została zepchnięta na margines bałkańskiej pamięci publicznej. Po drugie, zacieranie znajomości niektórych wątków II wojny światowej stanowiło element politycznej propagandy. Usuwanie ich z pamięci przyjmowało niejednokrotnie formę fizycznego niszczenia czy rozbierania budowli bądź po prostu zmieniania ich funkcji. Cenzura mówienia o Holokauście została zdjęta w Polsce na przełomie lat 80. i 90. XX wieku. Wciąż pozostają jednak puste plamy w historii II wojny światowej, podejmowane są też próby ingerencji i przekształcania niektórych jej wątków. Po trzecie, doprowadzenie do całkowitej utraty pamięci było bardzo ważnym narzędziem Holokaustu. Wydaje się, że najbardziej okrutnym. Finalnym efektem działań nazistów miało być ostateczne unicestwienie - gdy zanika pamięć o danej społeczności i jej kulturze, giną one całkowicie.

${ }^{36}$ A. Funkenstein: Perceptions of Jewish History. Berkerley 1993.

${ }^{37}$ J. Suвотіс: Why the Yougoslav Memorial Pavillon at Auschiwtz Stand Empty. https://balkaninsight.com/2020/01/24/why-the-yugoslav-memorial-pavilion-atauschwitz-stands-empty/?fbclid=IwAR0ZJ6RdwMxyvXE1ozrltVvTgyyiXy57AejL 16CDh-V60pl-qxkK0mV_wrE [dostęp: 22.01.2020]. 
Działania artystów na rzecz zachowania pamięci stają się jednocześnie protestem wobec idei nazistowskiej. Twórcy post-pomników, przywołując miejsca pamięci indywidualnej, przeciwstawiają się zapomnieniu i starają się w widoczny sposób uobecnić przeszłość. Ich sztuka, mówiąc językiem Susan Sontag ${ }^{38}$, to substytut obecności oraz wspólnoty.

Autorzy post-pomników skupiają się na stosunku sztuki do czasowości. Odrzucają lub renegocjują tradycyjne formy i powody publicznej sztuki pamiętania, takie jak ekspansja i trwałość, figuratywna reprezentacja i gloryfikacja minionych czynó $w^{39}$. Ich artystyczna aktywność ma za zadanie rekonstrukcję obumarłych miejsc i zapomnianych faktów, staje się antidotum na brak pamięci. Obecność w dziele sztuki ma zastąpić nieobecność, tematyzować ją, dawać świadectwo przeszłości oraz traumy. Post-pomniki czynią to, nie tylko wskazując na nie-miejsca pamięci, miejsca czy postaci zapomniane, ale też istniejąc tylko przez chwilę. Zauważone przez nielicznych, stają się ulotne niczym pamięć. Uświadamiają pustkę, chwilowość i nietrwałość, co dotyczy zarówno pamięci, jak i pomników, które niszczeją są burzone i zapominane. Za Erickiem Jacobsonem można zatem nazwać post-pomnik reprezentacją miejsca nieobecności i pustki ${ }^{40}$. Co istotne, nie ingeruje on jednak w przestrzeń na stałe, lecz przywołując najistotniejsze cechy pamięci: chwilowość i wybiórczość, staje się dziełem incydentalnym. Przypomina o miejscu czy wydarzeniu, a równocześnie ukazuje, jak działa pamięć i czas. W codziennym biegu ślady przeszłości zazwyczaj są przecież omijane, czasami całkowicie bezmyślnie, czasami zauważane tylko na chwilę.

Pamięć aktualizowaną przez post-pomniki można zatem nazwać nomadyczną - to pamięć przemieszczająca się wraz z tempem ruchu przechodniów, ale również wędrująca wraz z pamięcią artysty. Post-pomnik zachęca do zatrzymania się na chwilę, odnalezienia w sobie historycznej wrażliwości, poddania się zmysłowym i intelektualnym doznaniom. Takie pamiętanie, według twórców, to akt humanizacji i podmiotowości, który stanowi warunek bycia człowiekiem i zarazem klucz do wszelkich aktów tożsamościowotwórczych.

Sama chwilowość wpisana jest w temat Holokaustu. Jak podkreśla Irena Grudzińska-Gross:

38 S. Sontag: O fotografii. Przeł. S. Magala. Warszawa 1986.

39 Zob. J.E. Young: The Counter-Monument: Memory Against Itself in Germany Today. "Critical Inquiry” 1998, no 2, s. 272.

${ }^{40}$ E. Jacobson: Das Kunstwerk und die Erinnerung. Dem Vergangenen im Bild eine Präsenz geben. Graz 2011, s. 46. 
Prawda o Zagładzie jest trudna do uchwycenia, nie tylko dlatego, że należy do przeszłości, a przeszłość jest jak matowa szyba, przez którą źle widać. Każda myśl o Holokauście musi więc być odkryciem, ale tylko chwilowym, bo zaraz od siebie odpycha jak wszelkie zetknięcie z przemocą ${ }^{41}$.

Ze względu na zasadniczą trudność i wyjątkowość, nieprzedstawialność, bezpostaciowość czy niematerialność doświadczenia Zagłady, pamięć o Holokauście nie musi być stała i pomnikowa. Powinna pozwalać na złapanie oddechu, by z nową siłą móc wracać do zapomnianych miejsc i wypełniać je na chwilę pamięcią. Post-pomniki zatem przypominają zapalony na grobie znicz czy położony na nim kamień. Świadczą o pamięci i podejmowaniu chwilowych, memoratywnych działań. Po nich każdy powinien wrócić do teraźniejszości, naznaczonej wprawdzie cieniem przeszłości, lecz nie samą przeszłością. Z tego powodu twórcy post-pomników anektują przestrzeń zazwyczaj tylko na jakiś czas lub starają się, aby ich forma nie narzucała się i nie wymuszała patosu.

Taka była m.in. Pływalnia Rafała Jakubowicza - krótka projekcja prezentowana na zewnątrz budynku dawnej synagogi w Poznaniu. Hebrajski zapis słowa na pływalni, którą obecnie jest przedwojenny dom modlitwy, miał przypominać o ówczesnym przeznaczeniu miejsca, ale również wpisywać je na powrót do świata kultury żydowskiej. To samo miejsce stało się także przestrzenią performansu Rafała Betlejemskiego, który na tle zapomnianej synagogi wykonał fotografię grupy osób z umieszczonym pośrodku pustym krzesłem. Temat nicości czy nie-miejsca to bez wątpienia motyw przewodni murali tego artysty, ale także budowli rozpoznawanych jako sztandarowe post-pomniki, takich jak Holocaust-Mahnmal w Wiedniu, stojący w miejscu zapomnianej średniowiecznej synagogi. Dzieło Racheli Whiteread przedstawia tajemniczą, opustoszałą, wiecznie zamkniętą bibliotekę, która skrywa tajemnicę miejsca i społeczności zamieszkującej niegdyś Judenplatz. Z jednej strony nawiązuje do zapomnienia wymarłej czy wymordowanej kultury, z drugiej pozostaje w jawnej sprzeczności z obecną architekturą jego otoczenia. Post-pomnik Whiteread, podobnie jak krakowski post-pomnik na placu Bohaterów Getta, gdzie ustawiono krzesła-pomniki oraz zwykłe krzesła do siedzenia z żeliwa i brązu, symbolizujące eksterminację Żydów, zaczyna znaczyć wtedy, gdy pozna się historię miejsca. Odniesienia do przeszłości są dyskretne. Post-pomnik to znak pamięci dla wtajemniczonych, np. czytelników wspomnień

${ }^{41}$ I. GrudzińsKa-Gross: [Esej bez tytułu]. W: Wielogłos o Zagładzie..., s. 80. 
aptekarza Tadeusza Pankiewicza. Inni przechodnie po prostu go mijają. Podobnie działała instalacja Anny Baumgart i Agnieszki Kurant, które nad ulicą Chłodną, w miejscu przerzuconego przez nazistów w 1942 roku drewnianego mostu łączącego małe i duże getto, zawiesiły wielokropek (choć początkowo miał to być most ze srebrnych balonów). Znak graficzny, który wskazuje pominięte fragmenty, wycięte z tekstu-pamięci, wymownie podkreślał, że historia tego miejsca pozostała tylko w świadomości jej świadków i osób, które ją poznały. Dla pozostałych to tylko wielokropek. Post-pomnik dyskretnie kieruje zatem uwagę na niezauważalną przeszłość oraz wykluczoną społeczność. W Lublinie, na terenie dawnej dzielnicy żydowskiej, przy zbiegu dzisiejszej ulicy Krawieckiej i Podwala stoi zachowana sprzed II wojny światowej Latarnia pamięci, niegasnąca od 2004 roku. Niczym synagogalne ner tamid świeci, by upamiętnić, jak głosi napis na tablicy, świat, którego już nie ma, i jego mieszkańców. Latarnia ta w większym stopniu pełni funkcję Denkmal, który przypomina o pewnych faktach, niż Ehremal, który ma uczcić daną postać czy wydarzenie.

Przypominanie, opowiadanie i obrazowanie przeszłości sprawiają, że minione staje się choć na chwilę obecne i aktualne. $W$ ten sposób artyści post-pomników zapełniają lukę między przeszłością a teraźniejszością, historią a współczesnością, pamięcią a zapomnieniem, zbiorowością a jednostką i pozwalają ponownie zreinterpretować dziedzictwo oraz tożsamość. Istotnym jej elementem jest trauma, sposób jej oswajania, przeżycia czy wyrażania.

Post-monumentalne działanie nawiązuje do idei pomnika, ale ją dekonstruuje, subiektywizuje i uaktywnia. Poszukuje remedium na świadomość nieprzystawalności Holokaustu ${ }^{42}$. Współczesny post-pomnik, nazywany niekiedy pomnikiem dialogicznym (dialogic monument ${ }^{43}$ ) to prowokacja dialogu czy zderzenie dialogicznej wyobraźni z przestrzenią i czasem - teraźniejszością, przeszłością i przyszłością, ale też różnymi sposobami upamiętniania publicznego i prywatnego, politycznego i odpolitycznionego, ideologizowanego lub pozbawionego ideologii. Umberto Eco pisze, że post-pomnik to dzieło „pracy otwartej"44 w sensie koncepcyjnym i interpretacyj-

${ }^{42}$ M. Kıтошsка-Łysıак: Jakich pomników potrzebuja ocaleni? W: Wobec formy otwartej Oskara Hansena: idea - utopia - reinterpretacje. Red. M. LachowsкI, M. Linкошsка, Z. SовсZuк. Lublin 2009, s. 191.

${ }^{43}$ Q. Stevens, K.A. Franck, R. Fazakerley: Counter-Monuments: The Anti-monumental and the Dialogic. „The Journal of Architecture” 2014, vol. 17, no 6, s. 952.

${ }^{44}$ U. Eco: The Open Work. Transl. A. Cancogni. Cambridge 1989. 
nym, a Jacobson, że to akt nieustannego przetwarzania, pozostawania $\mathrm{w}$ procesie, co czyni sztukę podobną do życia pozagrobowego, pozbawia ją początku i końca.

Jako przykład otwartości post-pomnika może służyć niezrealizowany projekt Oskara Hansena pt. Droga. Zespół pod jego kierunkiem zaproponował potraktowanie całego obozu Auschwitz jako pomnika. Wizualnym i jedynym trwałym elementem miała być asfaltowa droga przecinająca obóz, pozostałe jego części: baraki, kominy, krematoria, ogrodzenia, rampa kolejowa, miały zostać poddane niszczycielskiemu działaniu czasu. Klasyczną formą upamiętniania byłyby jedynie indywidualne gesty - zapalenie znicza, położenie kamyków. Droga miałaby grubą kreską odcinać czy przekreślać przeszłość, której nie można powtórzyć. Jak zaznaczał Hansen:

Proces zachodzący poza drogą odgrywałby rolę zegara biologicznego. Rosły już tam drzewa, widzieliśmy przebiegające jelenie i sarny. Chcieliśmy elementy na drodze zakonserwować - utrwalić ogólnoludzkie doświadczenie dla innych, tak jak Pompeje utrwaliła lawa. Pomnik "Droga” jest poszukiwaniem ciągłości. Wyrusza ona z życia, przechodzi przez śmierć, a następnie znowu wraca do innego życia. Życie i śmierć określają się wzajemnie przez siebie ${ }^{45}$.

Niepomnikowa inicjatywa zespołu Hansena nie spotkała się z aprobatą byłych więźniów Auschwitz. Wskazała jednak drogę odchodzenia od koncepcji figuratywnego, mitologizującego pomnika na rzecz działania symbolicznego, niekończącego się procesu czy idei site specific. Post-pomnik bowiem niczym ready-made stawiany jest $\mathrm{w}$ miejscu odnalezionym, często peryferyjnym, ale autentycznym, ukształtowanym przez historię i indywidualną pamięć. Odwołuje się do niego, ale pozostaje też otwarty na polisemię interpretacyjną, pozwala na wiele odczytań, z których żadne nie zostaje uznane za dominujące lub poprawne, poddaje pod dyskusję wybrane wątki, zachęca do szukania znaczeń, związków, snucia historii oraz jej dopowiadania. Często nie eksponuje celu, nie sięga po oficjalne narracje, a jeśli już - to jedynie po to, by je odrzucić czy ośmieszyć. Nie ma tytułu i zakłada, że może pozostać niezauważony. Dostrzeżenie go jest dobrowolne, nierzadko przypadkowe. Nie wymusza na odbiorcy zainteresowania, aczkolwiek stara się go na tyle zaciekawić, by zwrócić uwagę na swoje przesłanie. Post-pomnik ma bowiem skłonić

${ }^{45}$ https://culture.pl/pl/tworca/oskar-hansen [dostęp: 07.05.2019]. 
do indywidulanej refleksji. Hansen podkreśla, że taka forma wypowiedzi artystycznej może być traktowana jako włączenie jednostki do kolektywu, znalezienie dla niej miejsca w określonej zbiorowości, a nawet uczynienie z niej niezbędnego elementu, kształtującego ową społecznośćc ${ }^{4}$. I właśnie otwarta forma, jego zdaniem, umożliwia wyrażenie czy wyeksponowanie indywidualnej perspektywy.

Post-pomnik, dzięki nietypowej formie, przeciwstawia się uproszczeniom i schematyzacji, charakterystycznym dla realizacji pomnikowych. Zakłada on aktywną postawę odbiorcy, którego zadanie jest o wiele trudniejsze niż $\mathrm{w}$ przypadku kontaktu z pomnikiem. Post-pomnik bowiem nie tyle upamiętnia, ile dokonuje swoistej rewindykacji pamięci. Prowadzi grę z odbiorca, jego wrażliwością, potrzebą poznawczą, tożsamością. Wymaga nie tylko zastanowienia, ale również dotarcia do informacji, do których się odnosi - a często są to świadectwa pojedynczych osób. Bez nich trudno zrozumieć jego sens, dopatrzeć się przesłania. Dopiero research pozwala na uchwycenie treści, namysł nad nią i emocjonalny odbiór. Post-pomnik czyni zatem odbiorcę aktywnym czy transaktywnym współtwórcą znaczenia.

Post-pomniki tematyzujące postpamięć post-Holokaustu wskazują na wielość doświadczeń traumatycznych, które trudno wyrazić $\mathrm{w}$ formie klasycznego pomnika. Stawiają na eksperyment artystyczno-społeczny. To, że dotyczą przemocy i tragedii jednostki, nie pozwala na pomnikowe przedstawienie bólu, lęku i wszystkich, towarzyszących ofiarom Holokaustu, emocji. Unikanie podniosłych narracji i wielkich kwantyfikatorów umożliwia skupienie się na przeżyciach indywidualnych oraz ich wpływie na teraźniejszość kolejnych pokoleń. Uaktywnienie widza przeciwdziała zapominaniu i zachęca do dialogu. Post-pomniki stawiają bowiem nie tylko na rozumowe podejście do dzieła, ale również na emocje i empatię. Ta ostatnia nie oznacza jednak, jak u Jill Bennett ${ }^{47}$, podzielania doświadczenia czy rozpoznania doświadczenia innych jako swojego, ale sugeruje samodzielne doświadczanie, własny sposób myślenia i rozumienia emocji, charakteru relacji międzyludzkich, przemocy, bólu i rozpaczy.

Peter Eisenman, autor berlińskiego (post)pomnika ofiar Holocaustu, który propaguje ideę wyzwolenia i niezależności dzieł architek-

${ }^{46}$ O. Hansen: Forma otwarta w architekturze. Sztuka wielkiej liczby. W: Wobec formy..., s. 15 .

${ }^{47}$ J. Bennett: Empathic Vision. Affect, Trauma, and Contemporary Art. Stanford 2005 . 
tonicznych, pozwala na każdą formę doświadczania jego pomnika, godzi się nawet na jeżdżenie po nim na rolkach, rowerach, spacery po nim z psem, a nawet spożywanie na nim posiłków i alkoholu. Najważniejsze jest to, aby post-pomnik był komentowany, istniał w opinii i pamięci społecznej, angażował uwagę. Łukasz Posłuszny, oceniając zamysł Eisenmana, pisze, że miejsce pamięci „byłoby [...] wtedy na zawsze miejscem ciągłej dyskusji, a może i sporów, gdzie pamięć pozostawałaby żywszą, a odpowiedzialność obywatelska rosła w siłę. [...] Czasem lepsze okazuje się tysiąc lat dyskusji niż ostateczne rozwiązanie problemu pomników"48. Podobnie jak Eisenman, wypowiada się polski autor post-pomników Mirosław Bałka, który w 2009 roku stworzył siedemnastometrowy tunel $\mathrm{z}$ betonu z wyciętym napisem: „AUSCHWITZWIELICZKA”, ukazując oba miejsca jako cel turystycznej wyprawy, a nie zadumy nad przeszłością. Tunel stał w Krakowie w dwóch miejscach i poddawany był aktom wandalizmu, które artysta traktował jako naturalną dewastację, a zarazem metaforę dewastacji pamięci i rangi wydarzeń historycznych we współczesnej świadomości. Nawiązując do myśli Younga ${ }^{49}$, można zinterpretować niszczony post-pomnik jako lustro społeczeństwa, przypomnienie o obcości opinii publicznej wobec kłopotliwej przeszłości i różnych form jej upamiętniania.

\section{Podsumowanie}

Post-pomniki wpisują doświadczenie $\mathrm{w}$ przestrzeń miasta, nie czynią tego jednak w sposób ciężki i monumentalny. Nie są to figury wspólne dla wszystkich obywateli, nakłaniające do zbiorowych rytuałów, ale miejsca zadumy jednostki nad przeżyciami innej jednostki. Post-pomniki nie zmuszają do uroczystych obchodów, a jedynie zapraszają do wspólnego pochylenia się nad konkretną treścią pamięci tych, którzy czują taką potrzebę. Prowokują, pobudzają do zmian, otwierają się na multiwersalistyczną interpretację, stawiają pytania, na które nie zawsze udzielają odpowiedzi, domagają się interakcji, a potem znikają. $W$ ten sposób nadają znaczenie przypominanemu. To performatywne świadczenie czy uobecnienie, przepracowywanie

48 Ł. PosŁuszny: Miejsca pamięci: przestrzeń - pamiętanie - zapominanie. W: Miejsca pamięci w świadomości współczesnego człowieka. Red. K. ZieLIŃsKI, J. JANIKowSKA. Toruń 2015, s. 28.

49 J.E. Young: Memory/monument. In: Critical Terms for Art History. Eds. R.S. Nelson, R. Schiff. Chicago 2003. 
traumy „odczuwanej - jak zaznacza LaCapra - w szerszym społecznym i kulturowym otoczeniu" ${ }^{\prime 50}$.

Wydaje się, że najtrafniej można zdefiniować post-pomnik, parafrazując opis czterech cech, które przypisuje mu James E. Young: post-pomnik nie utwierdza $\mathrm{w}$ przekonaniu o istnieniu prawdy o danym wydarzeniu, ale wyraża sprzeciw wobec ideologicznie traktowanej przeszłości i wprowadza indywidulany punkt widzenia, unika monumentalnej formy i przez to staje się czasami niewidoczny, zaprasza odbiorców do bliskiego, wielosensorycznego zaangażowania oraz unika funkcji dydaktycznej, a zamiast niej proponuje dialog, interpretację, poszukiwanie źródeł. Post-pomnik jako forma postmodernistycznej ${ }^{51}$ wypowiedzi nie tylko odkrywa nowe tematy czy miejsca, ale je wytwarza, pozwala na ich nowe odczytania oraz przypomina o przeszłości na nowo. Dzieje się tak być może dlatego, że tworzony jest coraz częściej przez post-pokolenie wychowane w postholokaustowym czasie, którego potrzeba podjęcia tematu Zagłady nie wynika z konieczności wypowiedzenia się na temat własnych przeżyć, lecz bierze się z imperatywu świadczenia o przeżyciach innych. To kolejny krok - jak zaznacza Delfina Jałowik - w przekazywaniu doświadczenia Zagłady. Twórcy ci „nie zostali dotknięci osobiście tą tragedią. Stanowią oni przykład niezwykłej wrażliwości na zło, z którym trudno sobie poradzić. Dzięki nim powstaje język symboli i metafor ${ }^{\prime \prime 2}$.

Nowy dyskurs sztuki pomnikowej to zarazem nowa metoda ukazania tego, co minione i zapomniane, zależna od artysty oraz odbiorcy-współkreatora sensu artystycznej wypowiedzi. Twórca pozwala sobie na pewne manipulacje, szokowanie, prowokowanie, by pobudzić wyobraźnię, ciekawość poznawczą i otwartość interpretacyjną. Aranżuje zatem lub inscenizuje sytuację spotkania i poszukiwania informacji. Punktem wyjścia swoich prac czyni napięcie między tym, co pamiętane i zapominane. W ten sposób osłabia przekonanie o obiektywności historii, prawdziwości jej przekazu, pewności faktów i nadaje temu, co zapamiętane, przypomniane i odpominane charakter jednostkowego, chwilowego spotkania z przeszłością. Artysta odkrywa tym samym nowe spojrzenie na

${ }^{50}$ D. LaCapra: Historia w okresie przejściowym. Doświadczenie, tożsamość, teoria krytyczna. Przeł. K. Bojarska. Kraków 2009, s. 178.

${ }^{51}$ Zob. charakterystykę postmodernistycznych praktyk M. KöHLER: Arranged, Constructed and Staged - From Talking to Making Pictures. In: Constructed Realities: The Art of Staged Pohotography. Ed. M. KöHLER. Zürich 1989.

${ }^{52}$ D. JАєошік: Narracja o Zagładzie. W: Wielogłos o Zagładzie..., s. 102-103. 
przeszłość oraz teraźniejszość, inicjuje aktywną interpretację faktów, pamięci zbiorowej i indywidualnej, uruchamia pokłady wrażliwości i empatii, potęguje świadomość negatywnego dziedzictwa. Z wielu pamięci i różnych interpretacji przeszłości buduje pluralistyczną wizję tożsamości każdego obiorcy. Równocześnie nie ocenia pejoratywnie zapominania, a czyni $\mathrm{z}$ niego element teraźniejszości i dziejowości. Ukazuje, że każda pamięć jest ważna hic et nunc.

\section{Bibliografia}

Arendt H.: Kondycja ludzka. Przeł. A. ŁagodzKa. Warszawa 2000.

Arendt H.: The Human Condition. Chicago 1998.

Bauman Z.: Świat nawiedzony. W: Zagłada. Wspótczesne problemy. Red. P. CzaplińSKi, E. Domańska. Poznań 2009, s. 48-58.

Benjamin W.: On the Concept of History. https://www.marxists.org/reference/ar chive/benjamin/1940/history.htm [dostęp: 7.06.2019].

Benjamin W.: The Work of Art in the Age of Its Technological Reproducibility. In: Walter Benjamin: Selected Writings. Vol. 3: 1935-1938. Eds. H. Eiland, M.W. Jennings. Cambridge-London 2002, s. 19-55.

Bennett J.: Empathic Vision. Affect, Trauma, and Contemporary Art. Stanford 2005. Berger J.: After the End. Representations of Post-Apocalypse. Minneapolis 1999.

Czapliński P.: Zagłada - niedokończona narracja polskiej nowoczesności. W: Ślady obecności. Red. S. BuryŁA, A. Molisak. Kraków 2010, s. 337-382.

DĄвRowski B.: Postpamięć, zależność, trama. W: Kultura po przejściach, osoby z przeszłości. Polski dyskurs postzależnościowy - konteksty $i$ perspektywy badawcze. Red. R. Nycz. Kraków 2011, s. 257-270.

Dekoven E.S.: Representating Auschwitz. „History and Memory. Studies in Representation of the Past", vol. 7, no 2, s. 121-154. https://www.jstor.org/ stable/25618691?seq=1\#page_scan_tab_contents [dostęp: 19.04.2019].

Domańska E.: "Niechaj umarli grzebia żywych". Monumentalna przeciw-Historia Daniela Libeskinda. „Teksty Drugie” 2004, nr 1-2, s. 78-102.

Eco U.: The Open Work. Transl. A. Cancogni. Cambridge 1989.

Fenz W.: The Monument Is Invisible, the Sign Visible. "October" 1989, vol. 48, s. $173-182$.

Funkenstein A.: Perceptions of Jewish History. Berkerley 1993.

Gerz J.: [Esej bez tytułu]. W: Wielogłos o Zagładzie. Red. M.A. РотоскA. Kraków 2018, s. 66-67.

Grudzińska-Gross I.: [Esej bez tytułu]. W: Wielogłos o Zagładzie. Red. M.A. РотосKA. Kraków 2018, s. 80-81.

Hansen O.: Forma otwarta w architekturze. Sztuka wielkiej liczby. W: Wobec formy otwartej Oskara Hansena: idea - utopia - reinterpretacje. Red. M. LAchowsкI, M. Linкоwsка, Z. Sовсzuк. Lublin 2009, s. 15-31.

Hirsch M.: Family Frames: Photography, Narrative, and Postmemory. CambridgeMassachusetts-London 1997. 
Hirsch M.: Family Pictures: Maus, Mourning and Post-Memory. „Discourse”, Winter 1992/1993, s. 3-29.

Hirsch M.: Projected Memory: Holocaust Photographs in Personal and Public Fantasy. In: Acts of Memory. Cultural Recall in the Present. Eds. M. BaL, J. Crewe, L. SPITZER. London-Hanover 1999, s. 2-23.

Hirsch M.: Surviving Images: Holocaust Photographs and the Work of Postmemory. „The Yale Journal of Criticism” 2001, vol. 14, no 1, s. 5-37.

Hirsch M.: The Generation of Postmemory: Writing and Visual Culture After the Holocaust. New York 2012.

Hoffmam E.: After Such Knowledge. A Meditation on the Aftermath of the Holocaust. London 2005.

Hutton P.H.: History as an Art of Memory. Hanover-London 1993.

Huyssen A.: Monumental Seduction. „New German Critique” 1996, no 69, s. $181-200$.

Huyssen A.: Monumental Seduction. In: Acts of Memory. Cultural Recall in the Present. Eds. M. Bal, J. Crewe, L. Spitzer. Dartmouth 1999, s. 191-207.

Jacobson E.: Das Kunstwerk und die Erinnerung. Dem Vergangenen im Bild eine Präsenz geben. Graz 2011.

Jаєошік D.: Narracja o Zagładzie. W: Wielogłos o Zagładzie. Red. M.A. Ротоска. Kraków 2018, s. 101-104.

JedlińsKa E.: Sztuka po Holokauście. Łódź 2001.

Kalaga W.: Memory, Interpretation, Identity. Przeł. J. Pytalski. „Teksty Drugie” 2016, nr 1, s. 20-35.

Kiтоwsка-Łysiak M.: Jakich pomników potrzebuja ocaleni? W: Wobec formy otwartej Oskara Hansena: idea - utopia - reinterpretacje. Red. M. Lichowsкi, M. LinkowSKA, Z. SовсZUк. Lublin 2009, s. 189-208.

KLeIN K.L.: O pojawieniu się pamięci w dyskursie historycznym. Przeł. M. BańkowsKi. „Konteksty” 2003, nr 3/4, s. 42-56.

KLEIN K.L.: On the Emergence of Memory in Historical Discourse. „Representations” 2000, no 69, s. 127-150. http://marcuse.faculty.history.ucsb.edu/classes/201/art icles/00KleinMemoryHistDiscourseRep.pdf [dostęp: 29.04.2019].

KöHLer M.: Arranged, Constructed and Staged - From Talking to Making Pictures. In: Constructed Realities: The Art of Staged Pohotography. Ed. M. KöHLER. Zürich 1989.

Krauss R.E.: Oryginalność awangardy i inne mity modernistyczne. Tłum. M. Szuba. Gdańsk 2011.

LaCapra D.: Historia w okresie przejściowym. Doświadczenie, tożsamość, teoria krytyczna. Przeł. K. Bojarska. Kraków 2009.

LaCapra D.: Trauma, Absence, Loss. "Critical Inquiry” 1999, vol. 25, no 4, s. 696727. https://www.jstor.org/stable/pdf/1344100.pdf?seq=1\#page_scan_tab_contents [dostęp: 05.05.2019].

LaCapra D.: Writing History, Writing Trauma. Baltimore 2001.

Масн A.: Polska kondycja posttraumatyczna. W: Kultura po przejściach, osoby z przeszłości. Polski dyskurs postzależnościowy - konteksty i perspektywy badawcze. Red. R. Nycz. Kraków 2011, s. 217-238.

Musil R.: Die Denkmale. In: Inem: Nachlass zu Lebzeiten. Hamburg 1980. 
Musil R.: Posthumous Papers of a Living Author. Transl. P. Wortsman. Colorado 1987.

Neumanm A.: On Experience, Memory, and Knowing: A Post-Holocaust (Auto)Biography. „Curriculum Inquiry” 1998, no 28(4), s. 425-442.

PosŁuszny Ł.: Miejsca pamięci: przestrzeń - pamiętanie - zapominanie. W: Miejsca pamięci w świadomości współczesnego człowieka. Red. K. Zieliński, J. JanikowSKA. Toruń 2015, s. 131-142.

Radstone S.: Reconceiving Binaries: The Limits of Memory. „History Workshop Journal" 2005, no 59, s. 134-150.

Radstone S.: Screening Trauma: Forrest Gump, Film and Memory. In: Memory and Methodology. Ed. S. Radstone. Oxford-New York 2000, s. 79-108.

Rothberg M.: Traumatic Realism. The Demands of Holocaust Representation. Minneapolis- London 2000.

Savage K.: Monument Wars: Washington, D.C. the National Mall, and the Transformation of the Memorial Landscape. London 2011.

Schudson M.: Watergate in American Memory: How We Remember, Forget, and Reoconstruct the Past. New York 1992.

Sontag S.: O fotografii. Przeł. S. Magala. Warszawa 1986.

Steinbach P.: Opór - sprzeciw - rezystencja. Postawy społeczności niemieckiej w Trzeciej Rzeszy a pamięć zbiorowa. Tłum. I. Ewertowska-Klaja. Poznań 2001.

Stevens Q., Franck K.A., Fazakerley R.: Counter-Monuments: The Anti-monumental and the Dialogic. "The Journal of Architecture" 2014, vol. 17, no 6, s. 951-972.

Sturken M.: Tangled Memories: The Vietnam War, the AIDS Epidemic, and the Politics of Remembering. Berkley 1997.

Suвотіс J.: Why the Yougoslav Memorial Pavillon at Auschiwtz Stand Empty. https:// balkaninsight.com/2020/01/24/why-the-yugoslav-memorial-pavilion-at-au schwitz-stands-empty/?fbclid=IwAR0ZJ6RdwMxyvXE1ozr1tVvTgyyiXy57Aej L16CDh-V60pl-qxkK0mV_wrE [dostęp: 22.01.2020].

Szahaj A.: Zniewalajaca moc kultury. Artykuty i szkice z filozofii kultury, poznania i polityki. Toruń 2004.

Szczepan A.: Polski dyskurs posttraumatyczny. Literatura polska ostatnich lat wobec Hokokausu i tożsamości żydowskiej. W: Kultura po przejściach, osoby z przeszłości. Polski dyskurs postzależnościowy - konteksty i perspektywy badawcze. Red. R. Nycz. Kraków 2011, s. 239-258.

Turowski A.: Pamięć Zagłady to monstrualny paradygmat. W: Wielogłos o Zagładzie. Red. M.A. Ротоска. Kraków 2018, s. 311-313.

Ubertowska A.: Świadectwo, trauma, głos. Literackie reprezentacje Holokaustu. Kraków 2007.

Vatтimo G.: Postnowoczesność i kres historii. Przeł. B. Stelmaszczyк. W: Postmodernizm. Antologia przekładów. Wybrał, oprac. i przedmową opatrzył R. Nycz. Kraków 1998, s. 128-144.

Yates F.: The Art of Memory. London 1966.

Young J.E.: At Memory's Edge. After-Images of the Holocaust in Contemporary Art and Architecture. New Haven-London 2000. 
Young J.E.: Memory/monument. In: Critical Terms for Art History. Eds. R.S. Nelson, R. Schiff. Chicago 2003, s. 234-247.

Young J.E.: Pamięć $i$ kontr-pamięć. W poszukiwaniu społecznej estetyki pomników Holokaustu. Tłum. G. DĄвrowsKi. „Literatura na Świecie” 2004, nr 1-2, s. $245-266$.

Young J.E.: Pamięć i kontrpamięć. W poszukiwaniu społecznej estetyki pomników Holokaustu. Tłum. G. Dąвrowski. W: Reprezentacje Holokaustu. Red. W. JARKIEwicz, M. Szuster. Kraków-Warszawa 2014.

Young J.E.: The Counter-Monument: Memory Against Itself in Germany Today. „Critical Inquiry" 1998, no 2, s. 267-296.

Young J.E.: The Stages of Memory: Reflections on Memorial Art, Loss, and the Spaces Between (Public History in Historical Perspective). Amherst 2016.

Zelizer B.: Introduction: On Visualizing the Holocaust. In: Visual Culture and the Holocaust. Ed. B. ZeLizer. London 2001.

http://4.s32.scripts.mit.edu/fall2014/wp-content/uploads/2014/10/Monumental-Se duction.pdf [dostęp: 29.04.2019].

Kinga Anna Gajda - adiunkt w Instytucie Europeistyki UJ, gdzie m.in. prowadzi serwis kompetencji międzykulturowych. Z wykształcenia teatrolożka, dramatolożka, europeistka. Ukończyła również podyplomowe gender studies. Doktorat uzyskała z literaturoznawstwa, a habilitację z dziedziny nauki o kulturze i religii. Jest autorką książek: Medea dzisiaj, która traktuje o performatywnej tożsamości kobiety jako Innego oraz Edukacyjna rola muzeum. Obecnie prowadzi badania z zakresu edukacji kulturalnej oraz dziedzictwa i pamięci.

e-mail: kinga.gajda@uj.edu.pl 